\title{
HAJI SULAWESI SELATAN PADA MASA NEGARA INDONESIA TIMUR (NIT) (1946-1950)
}

\section{THE PILGRIMAGE FROM SOUTH SULAWESI AT THE STATE OF EAST INDONESIA (1946-1950)}

\author{
Adil Akbar \\ SMAN 2 Makassar \\ Jln. Baji Gau III Nomor 17 Makassar, Indonesia \\ adilakbarilyasibrahimhusain@gmail.com
}

Diterima tanggal 1 Juli 2020

Disetujui tanggal 14 Juni 2021

\begin{abstract}
This article discusses two things. First, the historiography of the pilgrimage in South Sulawesi during the State of East Indonesia. Second, the correlation between rice and copra as commodities had impacts on economic growth in South Sulawesi. The method used in this article was the historical method by analyzing mainly contemporary archives. This study shows that the people in South Sulawesi can perform the pilgrimage due to the economic growth through rice and copra trade activities in this area, at least during the State of East Indonesia in 1946-1950. One of the benchmarks of economic growth is the number of people in South Sulawesi performing the pilgrimage, especially those who come from rice and copra producing areas.
\end{abstract}

Keywords: hajj, South Celebes, East State of Indonesia, rice, and copra.

\begin{abstract}
ABSTRAK
Artikel ini membahas dua hal. Pertama, historiografi haji di Sulawesi Selatan pada Masa Negara Indonesia Timur (NIT). Kedua, benang merah antara komoditas beras dan kopra terhadap peningkatan ekonomi di Sulawesi Selatan yang berdampak pada banyaknya masyarakat yang menunaikan ibadah haji di masa Negara Indonesia Timur. Metode yang digunakan dalam menyusun artikel ini ialah metode sejarah dengan menganalisis terutama arsip sezaman. Hasil dari penelitian ini menunjukkan bahwa masyarakat di Sulawesi Selatan dapat menunaikan ibadah haji dikarenakan adanya peningkatan perekonomian melalui kegiatan perdagangan beras dan kopra di daerah ini, setidaknya pada masa Negara Indonesia Timur pada periode 1946-1950. Salah satu tolok ukur dari peningkatan ekonomi tersebut adalah banyaknya masyarakat Sulawesi Selatan menunaikan ibadah haji terutama mereka yang berasal dari wilayah penghasil beras dan kopra.
\end{abstract}

Kata kunci: haji, Sulawesi Selatan, Negara Indonesia Timur, beras, dan kopra. 


\section{A. PENDAHULUAN}

"Ma'lumlah kiranja bahwa ibadah hadji itu adalah termasuk rukun Agama Islam jang kelima. Demikianlah maka tiap-tiap orang Islam jang telah dewasa, laki-laki atau wanita, bila memenuhi sjarat-sjarat menurut ketentuan Agama Islam, adalah diwadjibkan naik hadji atau mengundjungi Ka'bah di Makkah untuk menuaikan ibadah hadji." (Anonim 1953:612)

Sebagaimana yang telah diketahui secara umum, haji merupakan rukun Islam yang kelima. Haji dipandang sebagai penyempurna keislaman seseorang dan merupakan rangkaian tertinggi dalam ritual ibadah.

Pada abad ke-15 hingga abad ke18, sebelum ditemukannya kapal uap, perjalanan masyarakat menuju baitullah dilakukan dengan berbagai cara, mulai dari perjalanan darat hingga mengarungi samudra.

Putuhena (2007) dalam karyanya Historiografi Haji dan Azra (2004) dalam tulisannya Jaringan Ulama Timur Tengah dan Kepulauan Nusantara Abad XVII dan XVIII mengemukakan bahwa penduduk di Nusantara yang pertama melaksanakan ibadah haji merupakan para pedagang, utusan sultan, dan musafir penuntut ilmu. Di masa akhir abad ke-15 terdapat pedagang Arab dan Sumatra yang berlabuh di pelabuhan Aden dan Hormuz. Selain berdagang mereka menyempatkan untuk beribadah haji (Putuhena 2007:77,105). Pada 1556 diketahui lima kapal dari Kesultanan Aceh berlabuh di Jeddah. Kehadiran kapal tersebut, selain dalam misi perdagangan, juga menyempatkan menunaikan ibadah haji (Azra 2004:5051).

Kapal yang mengangkut jemaah haji pada masa itu adalah kapal dagang milik orang Arab dan India. Kebanyakan kapal-kapal tersebut berada di Singapura. Oleh sebab itu, calon jemaah haji asal Nusantara lebih senang ke Singapura atau Penang sebagai tempat embarkasi. Untuk memenuhi kebutuhan dalam membiayai keberangkatan ke Tanah Suci dan kepulangan mereka ke Nusantara, calon jemaah haji kadang bekerja sebagai buruh di pelabuhan atau bekerja di Singapura dan Penang. Hal tersebut memberikan konsekuensi tersendiri bagi calon jemaah haji (Chambert-Loir 2013:374-375).

Perjalanan menuju baitullah memakan waktu yang lama, yakni tiga sampai empat tahun, dengan pelayaran menuju Jeddah memakan waktu lima sampai enam bulan. Selain panjangnya perjalanan calon jemaah haji, hambatan utama yang dihadapi adalah ongkos yang mahal dan faktor lain seperti keadaan alam dan wabah penyakit (Chambert-Loir 2013:374375; Rohmatulloh 2017).

Secara umum, narasi sejarah perkembangan haji di Indonesia dapat dikatakan telah melalui serangkaian perjalanan yang panjang, dimulai sejak tumbuh dan berkembangnya Islam di Nusantara, masa penjajahan, revolusi kemerdekaan, hingga masa reformasi. Hanya saja, kapan umat Islam di Nusantara pertama kali melakukannya, tidak diketahui secara pasti.

Mereka menunaikan ibadah haji tidak hanya dilandasi oleh perintah agama, tetapi berkelindan dengan 
kegiatan berdagang dan menuntut ilmu.

Azra (2001:71) menjelaskan bahwa:

\begin{abstract}
Abad ke-16 jumlah Muslim yang datang dari berbagai penjuru Dunia Muslim ke Makkah semakin meningkat. Tetapi, tidak semua yang datang ke tanah suci merupakan ulama atau penuntut ilmu, kebanyakan mereka pada kenyataannya adalah jamaah haji biasa, yang ingin menunaikan kewajiban berhaji. Mereka ini biasanya kembali pada negara asalnya karena telah melaksanakan haji di Makkah dan mengunjungi tempat peristirahatan terakhir Nabi di Madinah. Namun demikian, terdapat sejumlah muslim yang datang ke Makkah tidak hanya untuk menunaikan ibadah haji, tetapi juga guna memenuhi tujuan-tujuan lain seperti memeroleh ilmu atau mengabdi diri melayani tempat-tempat suci.
\end{abstract}

Vrendebregt (1997) menyebutkan pada rentang abad ke-9 hingga abad ke20 terdapat lima daerah di Nusantara yang masyarakatnya memiliki animo tinggi dalam beribadah haji yakni, Jawa Barat, Jawa Tengah, Kalimantan Barat, Sumatra Barat, dan Sulawesi Selatan. Sementara jemaah haji asal Sulawesi Selatan baru terlacak sekurangkurangnya ketika wilayah ini mengalami proses Islamisasi di awal abad ke-17 (Sewang 2005). Noorduyn dalam ulasannya berjudul Islamisasi Makassar (2018) mengemukakan agama Islam setidak-nya tumbuh dan berkembang pada 1605 di Kerajaan Gowa, kemudian ke seluruh Sulawesi Selatan termasuk ke Kerajaan Bone pada 1611 (Noorduyn 2018:9-40).
Berkembangnya agama Islam di Sulawesi Selatan tentunya membawa pengaruh tersendiri dalam tatanan masyarakat, termasuk dalam urusan haji. Salah satu kisah yang merekam tentang jemaah haji asal Sulawesi Selatan ialah perjalanan Syech Yusuf Al Makassari, ulama terkenal dari Kerajaan Gowa-Tallo (Chambert-Loir 2013:171).

Terdapat sebuah narasi yang meriwayatkan Syech Yusuf meninggalkan Kerajaan Gowa-Tallo menuju Makkah. Namun sebelum ke Makkah, ia menyempatkan singgah dan menetap di Banten, Aceh, dan Gujarat untuk memperdalam ilmu agama. Baru sekitar 1649 ia melanjutkan perjalanan menuju Tanah Hejaz, perjalanan tersebut memakan waktu 56 hari. Ia menyempatkan juga ke Yaman untuk berguru pada Syekh Abi Abdillah Muhammad Abdul Al-Baqi A1Naqzabandi, Sayyid Ali Zubidi, dan Muhammad Al Wajih Al-Sa'di Al Yamani. Seusai berguru di Yaman, ia melanjutkan perjalanan menuju Makkah (Limpo et al. 1995:57-64).

Tidak diketahui persis kapan ia pulang ke Nusantara, namun diperkirakan ia berada di Kerajaan GowaTallo (Makassar) antara 1664 hingga 1672. Ada pula yang mengemukakan ia hanya sejenak di Makassar lalu menetap di Banten (Chambert-Loir 2013:172-173).

Di daerah lain, Segeri (sekarang bagian dari Kabupaten Pangkep) ada seorang ulama yang menyandang gelar haji bernama Puang Aji Sayye. Ada yang mengatakan, sosok Puang Aji Sayye ini adalah Sayyid Ja'far ulama dari Timur Tengah yang menetap di 
Segeri sejak kisaran abad ke-15. Selain itu, disebutkan pula masyarakat di wilayah ini mulai berhaji sekitar abad ke-19 (Syamsurijal et al. 2020:23)

Vredenbregt (1997) mengatakan bahwa pada 1664, tiga orang Bugis yang baru saja pulang dari ibadah haji dicekal oleh penguasa VOC untuk menambatkan kapalnya di Batavia. Bahkan ketiga orang tersebut ditangkap dan dibuang ke Tanjung Harapan.

Sejauh ini, belum ditemukan data terpercaya yang mengisahkan tentang masyarakat awal di Sulawesi Selatan yang melaksanakan ibadah haji. Akan tetapi, kemungkinan masyarakat di daerah ini melaksanakannya pada kisaran abad ke-17 sebagaimana yang diulas oleh Chambert-Loir. Paling tidak pada awal ketika Islam tumbuh berkembang di Sulawesi Selatan.

Meskipun keadaan pelayaran niaga ke Timur Tengah dan suasana politik dan ekonomi kadang menjadi hambatan, namun selama abad ke-15 hingga abad ke-18 masih banyak juga penduduk Nusantara yang pergi ke Makkah untuk menunaikan ibadah haji dan menimbah ilmu, seperti Abdurrauf Singkel (1615-1693), Syech Yusuf Al Makassari (1627-1699), Abdus Samad Al Palimbani (1704-1789), Arsyad Banjar (1710-1812), dan termasuk Abdul Qahhar Sultan Haji putra Sultan Agung Tirtayasa. Walaupun demikian, tidak dapat dinafikan terdapat pula calon jemaah haji yang gagal berangkat seperti yang dialami Adipati Cianjur dan Tumenggung Buitenzorg (Bogor) pada 1778 (Putuhena 2007:125).

Narasi haji di rentang abad ke-15 hingga abad ke-18 lebih banyak mengulas tentang riwayat para raja, sultan, bangsawan, dan utusan khusus kerajaan. Riwayat masyarakat biasa dalam menunaikan ibadah haji setidaknya tercatat di kisaran abad ke-19 hingga ke-20. Beberapa bab dalam buku Naik Haji di Masa Silam karya Chambert-Loir mengisahkan tentang seorang masyarakat biasa yang berhasil menunaikan ibadah haji, kisah itu tertuang di dalam Bab 17, Bab 21, dan Bab 22 (Chambert-Loir 2013:471-504; 665-698; 669-734).

Salah satu bab yang menarik dalam ulasan Chamber-Loir adalah naik haji di Masa Revolusi. Dalam tulisan tersebut, setidaknya diperoleh informasi mengenai rute pelayaran, kesulitan-kesulitan yang dihadapi selama perjalanan menuju Tanah Suci, serta suasana kebatinan para calon jemaah haji. Bab ini juga memberikan gambaran mengenai masyarakat biasa di Hindia Belanda juga mampu menunaikan ibadah haji dengan segala keterbatasan.

Walaupun demikian, tentang perjalanan jemaah haji dari wilayah timur Indonesia, terutama di Sulawesi Selatan masih belum mendapatkan ulasan yang mendalam. Padahal salah satu daerah yang menyumbang calon jemaah haji yang cukup banyak adalah Sulawesi Selatan sebagaimana yang dikemukakan oleh Vrendebregt (1997). Sebab, bagi masyarakat Sulawesi Selatan, menunaikan ibadah haji bukan semata perkara ibadah dan suatu upaya dalam menyempurnakan rukun Islam, tetapi terkait dengan tradisi lokal, status sosial, dan bahkan persoalan gaya hidup (Rifal 2013).

Pada 1898, hanya Batavia dan Padang yang dijadikan pelabuhan haji. 
Adapun Pelabuhan Makassar dijadikan pelabuhan haji sekitar 1922 (Syamsurijal et al. 2020:24). Dengan demikian dapat ditafsirkan bahwa sejak tahun tersebut telah ada masyarakat Sulawesi Selatan yang menunaikan ibadah haji walaupun jumlahnya hanya sedikit.

Pada perkembangan selanjutnya, antusiasme masyarakat Sulawesi Selatan dalam menunaikan ibadah haji dapat dikatakan cukup tinggi. Hal ini tercatat dengan jelas di kisaran 1946-1950, walaupun pada masa tersebut Sulawesi Selatan menjadi bagian dari Negara Indonesia Timur. Tercatat sebanyak 4835 jiwa masyarakat Sulawesi Selatan dari berbagai daerah menunaikan ibadah haji (ANRI Sulsel 1995 [Arsip Tana Toraja, No. Reg. 1416 dan 1420]:200).

Menunaikan ibadah haji di masa tersebut memiliki tantangan tersendiri. Pertama situasi Sulawesi Selatan, dan Indonesia pada umumnya yang kurang aman karena masih mengalami perundungan perang mempertahankan kemerdekaan (Hutagalung 2010). Kedua, adanya fatwa dari K.H. Hasjim Asj'ari (Ketua Partai Masjumi) pada 1947 yang menyatakan bahwa ibadah haji tidak wajib, malah boleh dipandang haram, selama perang melawan Belanda masih berlangsung (ChambertLoir 2013:669).

Meskipun begitu, minat untuk berhaji bagi masyarakat Sulawesi Selatan dan Indonesia pada umumnya tidak surut. Hal itu dapat dilihat dari surat/kawat Kementerian Penerangan RI c.q. Seksi Produksi Radio/ Djurnalistik H.O.I. No. 318, yang menyebutkan tentang kuota haji untuk
Indonesia. Di masa tersebut Indonesia mendapatkan jatah jemaah haji sebanyak 8.580 jiwa, sumber lain mengatakan kuota haji nasional di masa itu sebanyak 8.756 orang (Anonim 1948:1).

Di antara kuota tersebut NIT mendapatkan kuota sebanyak 1.500 jemaah, 925 jiwa dialokasikan untuk Sulawesi Selatan. Sedikitnya kuota tersebut tidak sebanding dengan antusiasme masyarakat yang berkeinginan menjadi tamu Allah. Tercatat 12.000 orang termasuk di Sulawesi Selatan, terpaksa menerima kenyataan bahwa permohonan izin berhaji yang diajukan harus ditolak karena kuota yang terbatas (ANRI Sulsel 1995 [Arsip Tana Toraja, No. Reg. 1420]:200).

Usaha masyarakat Sulawesi Selatan pada masa tersebut untuk melaksanakan rukun Islam yang terakhir tentunya membutuhkan biaya yang sangat besar. Para jemaah haji berangkat melalui Pelabuhan Makassar menuju Tanjung Priok dan dari mereka berlayar menuju Jeddah. Catatan arsip menyebutkan ongkos haji pada periode 1946-1950 berkisar $f 1.000$ lebih (ANRI Sulsel 1995 [Arsip Tana Toraja, No. Reg. 1416 dan 1420]:200; ChambertLoir 2013:702-713).

Fakta menunjukkan bahwa sejumlah masyarakat yang beribadah haji di tahun-tahun tersebut berasal dari daerah penghasil beras dan kopra, dua komoditas utama yang menggerakkan ekonomi Sulawesi Selatan. Daerah pertama adalah Afdeling Makassar, Afdeling Bone, Afdeling Bonthain, dan Afdeling Pare-Pare dikenal sebagai daerah penghasil beras (Anonim 1953:615-620). Sedangkan Afdeling 
Mandar dikenal sebagai daerah penghasil Kopra (Najamuddin 2000).

Ada dugaan kuat di masa tersebut roda perekonomian masyarakat berkembang begitu baik sehingga sejumlah masyarakat di Sulawesi Selatan dapat melaksanakan ibadah haji (Nur 2003). Dari sini muncul dua pertanyaan. Pertama, bagaimana perkembangan sejarah (historiografi) haji di Sulawesi Selatan pada masa NIT (1946-1950). Kedua, faktor apa yang menyebabkan masyarakat Sulawesi Selatan dapat menunaikan ibadah haji di masa NIT (1946-1950).

Tulisan ini bertujuan mengungkap narasi sejarah haji di wilayah Sulawesi Selatan. Begitu pula, faktor pendorong yang menyebabkan masyarakatnya dapat menunaikan ibadah haji pada kurun waktu 1946-1950.

Periode 1946-1950 dikenal sebagai satu masa di mana Indonesia sedang mempertahankan kemerdekaan. Di sisi lain, fakta menunjukkan sebagian dari masyarakat di masa tersebut melaksanakan ibadah haji di tengah situasi perang antara Indonesia dan Belanda.

Historiografi Indonesia sendiri di masa tersebut pada umumnya hanya mengungkap satu aspek, yakni romantika heroisme yang menyasar kalangan elite, sehingga aspek humanis atau aspek sosio-religiositas masyarakat di kalangan bawah terabaikan. Dengan demikian, akan menarik untuk mengulas peristiwa haji di masa tersebut dan kemudian menarik fenomena di masa lampau untuk dijadikan pembelajaran di masa sekarang, mengingat sejarah (peristiwa) yang dikenal (terjadi) sejak dahulu merupakan cerminan peristiwa di masa sekarang dan yang akan datang (Rahman 2015).

Dalam menyusun artikel ini, penulis menggunakan beberapa sumber rujukan. Beberapa di antaranya adalah buku Henri Chambert-Loir berjudul Naik Haji di Masa Silam Tahun 1482-1964 (2013). Pada jilid pertama (1482-1890) diulas pengalaman berhaji berbagai tokoh dari Malaka, Banten, Riau, Singapura, Sumedang, dan Aceh. Poin utama yang didapatkan di sini adalah kebanyakan para jemaah haji di masa ini berasal dari kalangan bangsawan atau utusan khusus kerajaan. Jilid kedua (1900-1950) meliputi kisah haji paruh pertama abad ke-20 yang merangkum kisah orangorang kecil yang menunaikan ibadah haji. Jilid ketiga (1954-1964) mengulas perjalanan haji yang mengalami perubahan mendasar, seperti urusan haji mulai dikelola profesional oleh pemerintah RI hingga catatan perjalanan haji oleh wartawan seperti Rosihan Anwar dan Saiful U.A.

Sekadar catatan, bahwasanya penulis hanya menggunakan dua jilid dalam buku tersebut. Jilid pertama membantu penulis membuka wawasan tentang haji di masa lampau, dan melihat bagaimana gambaran umum haji di kisaran tahun 1945-1950. Mengenai jilid kedua, ada ruang kosong yang hendak penulis isi melalui artikel ini, yakni historiografi haji di Sulawesi Selatan di masa 1946-1950.

Selain itu, karya Ahmad Faturrahman berjudul Berhaji pada Masa Kolonial Selebes Selatan 19471950 cukup banyak membantu penulis dalam mengurai permasalahan haji di Sulawesi Selatan. Namun terdapat 
kekurangan dalam karya tersebut, yakni tidak dikemukakannya perihal dari mana para calon jemaah haji tersebut mampu mendapatkan uang demi menutupi ongkos haji yang terbilang mahal. Ruang kosong inilah yang hendak penulis kemukakan dalam artikel ini.

\section{B. METODE}

Untuk menyusun artikel ini, dilakukan suatu penelitian dengan menggunakan metode sejarah. Metode sejarah tersendiri terbagi atas heuristik, kritik, interpretasi, dan historiografi. Artikel ini disusun dan dibangun berdasarkan analisis terhadap sumber-sumber sejarah berupa dokumen-dokumen, sumber tertulis, dan penelitian yang relevan dengan tema yang tersaji. Sifat dari penelitian ini adalah deskriptif analitis dengan menekankan pada aspek kronologis sebuah peristiwa.

Langkah yang pertama dilakukan dalam menulis artikel ini ialah heuristik. Secara sederhana, heuristik memiliki pengertian mengumpulkan sumber-sumber sejarah, mengumpulkan data-data sejarah (Sjamsuddin 2007:86). Untuk mengumpulkan datadata tersebut setidaknya dapat dilakukan dengan studi arsip dan studi kepustakaan.

Penelusuran arsip dilakukan di Dinas Perpustakaan dan Kearsipan Provinsi Sulawesi Selatan. Arsip yang paling utama digunakan adalah Arsip Pemda Tana Toraja, hal ini unik karena berita mengenai haji terekam dalam khazanah arsip tersebut, sedangkan wilayah tersebut di masa lalu dan masa sekarang adalah daerah yang mayoritas beragama Nasrani. Selain arsip yang telah disebutkan, digunakan pula beberapa arsip koleksi lain dari dinas tersebut

Langkah kedua ialah kritik yang terbagi atas kritik internal dan eksternal. Kritik internal dilakukan untuk menilai kelayakan atau kredibilitas sumber. Kredibilitas sumber biasanya mengacu pada kemampuan sumber untuk mengungkap kebenaran suatu peristiwa sejarah. Kemampuan itu meliputi kompetensi, kedekatan, atau kehadiran sumber dalam peristiwa sejarah. Selain itu, kepentingan dan subjektivitas sumber dan ketersediaan untuk mengungkapkan kebenaran. Konsis-tensi sumber terhadap isi atau sumber (Madjid dan Hamid 2011). Kritik eksternal dilakukan untuk mengetahui sejauh mana kebebasan dan autentikasi sumber. Kritik terhadap autentik sumber tersebut misalnya dengan melakukan pengecekan bahan berupa kertas atau tinta, apakah kertas atau tinta tersebut diproduksi pada kurun 1946-1950, memastikan suatu sumber apakah termasuk sumber asli atau salinan. Kritik internal di sisi lain melihat substansi dari sumber tersebut termasuk di dalamnya penggunaan ejaan.

Langkah berikutnya adalah interpretasi, yakni menafsirkan data dan fakta sejarah yang kemudian disusun menjadi satu jalinan peristiwa yang kronologis (Sjamsuddin 2007). Tahap terakhir adalah historiografi atau penulisan sejarah. Historiografi dilakukan dengan cara merekonstruksi cerita secara deskriptif naratif, yaitu menguraikan dalam bentuk cerita yang kronologis sehingga karya sejarah itu 
tersusun dalam bentuk cerita seperti karya-karya sastra (Priyadi 2015:79).

\section{HASIL DAN BAHASAN}

1. Historiografi Haji di Sulawesi Selatan pada Masa Negara Indonesia Timur (1946-1950)

Menunaikan ibadah haji bagi masyarakat Sulawesi Selatan bukan hanya sebagai bentuk penyempurna keimanan, tetapi juga prestise sosial. (Rifal 2013). Oleh karena itu, di dalam motivasi ibadah ada pula dorongan untuk menaikkan derajat sosial di hadapan masyarakat (Muhammadiyah 2006).

Putuhena mengemukakan sebuah artikel tentang interpretasi terhadap ibadah haji yang dinukil dari Indi Artikel. Daya tarik haji ada bermacammacam, di antaranya adalah: untuk menyatakan suatu keberanian, untuk menimbulkan rasa kebanggan dengan titel (gelar) haji, menjadikan orang terpandang karena telah menjalankan kewajiban agama, dan untuk melihat dunia lebih luas, dengan cara yang paling mudah (Putuhena 2007:151).

Melekatnya prestise sosial tersebut bukanlah tanpa alasan, mengingat sulitnya menunaikan ibadah haji pada masa tersebut. Pelaksanaan ibadah haji pada zaman dahulu dapat dikatakan jauh berbeda dengan pelaksanaan ibadah haji di masa sekarang. Ketika masa penjajahan hingga masa awal kemerdekaan, calon jemaah haji diangkut menggunakan kapal laut dan berlayar menuju Makkah. Perjalanan dari Pelabuhan Batavia (Tanjung Priok) ke Arab Saudi tentunya memakan waktu yang teramat panjang.
Vol. 4, No. 2, Juni 2021, hlm. 179-198

Mengingat mayoritas masyarakat Indonesia beragama Islam dan guna menjamin kepentingan jemaah haji dari Indonesia terutama Sulawesi Selatan, maka pada 16 Maret 1947 di Makassar didirikan suatu badan bernama Badan Penolong Djema'ah Hadji (B.P.D.H.) dibawah pimpinan H. Abdul Gaffar (Anonim 1953: 612). Badan inilah yang bertanggung jawab dalam melayani calon jemaah haji dari Sulawesi Selatan, mulai dari pemondokan di Makassar, hingga pengangkutan menggunakan kapal laut jemaah haji menuju Makkah.

Mengenai ongkos untuk beribadah haji, disebutkan sebesar $f 1.500$ (ANRI Sulsel 1995 [Arsip Tana Toraja, No. Reg. 1417 dan 1420]:200), sumber lain mengemukakan ongkos haji yang lebih mahal, yakni $f 1.836$ (Faturrahman, 2019:29) atau setara dengan Rp550 (kurs Rp1 rupiah setara dengan f0,3). Berdasarkan Undang-Undang Republik Indonesia Tahun 1946 pasal 1 bahwa Rp10 setara dengan lima gram emas murni atau Rp2 pada 1946-1947 setara dengan 1 gram emas. Artinya, nilai f1.836 setara dengan 225 gram emas.

Mahalnya ongkos haji dan minimnya peluang untuk berkesempatan menjadi tamu Allah menambah nilai tersendiri bagi masyarakat yang berhasil menjadi tamu Allah. Selain itu, tantangan menuju Makkah yang terbilang ekstrim, yakni mengarungi lautan dan memakan waktu berbulanbulan dari Pelabuhan Makassar ke Jeddah, Arab Saudi yang tentunya memakan biaya perjalanan yang tidak sedikit (Chambert-Loir 2013). Setidaknya para calon jemaah haji harus menempuh lebih 5.077 mil perjalanan 
laut dari Pelabuhan Makassar ke Pelabuhan Tanjung Priok lalu bertolak ke Pelabuhan Jeddah dengan rute Makassar-Tanjung Priok-SingapuraColombo-Aden-Jeddah (Anonim 1948).

Akan tetapi, hambatan-hambatan tersebut tidak menjadi halangan bagi masyarakat Sulawesi Selatan untuk menunaikan ibadah haji. Tiap tahun selama 1947-1950 sebanyak 1.200 jiwa lebih masyarakat asal Sulawesi Selatan melaksanakan ibadah haji (ANRI Sulsel 1995 [Arsip Tana Toraja, No. Reg. 1416 dan 1420]:200).

Sebagian besar dari mereka merupakan jemaah haji asal Afdeling Makassar, Pare-Pare, dan Bone (Anonim 1953). Tiga afdeling yang di masa tersebut merupakan daerah penghasil beras (Akbar 2016).

Jika ditelisik secara saksama, mayoritas umat Islam yang beribadah haji memiliki tingkat perekonomian rendah sehingga ibadah haji yang mereka tunaikan akan mempunyai nilai lebih, tidak hanya dikarenakan mereka menyisihkan pendapatan sebagai seorang petani ataupun pedagang kopra, mereka juga mengorbankan banyak harta benda, demi mencukupkan biaya untuk menunaikan ibadah haji. Hal tersebut tercermin dalam surat Zainial Abdin selaku Wedana Kalief Tana Toradja kepada Toean Ketoea Madjelis Tinggi Agama Tana Toradja dengan nomor 2/ W.K tertanggal 6 Mei 1948 yang bunyinya sebagai berikut.

"Berhoeboeng oleh karena mengingat peratoeran kenaikan Hadji pada tahoen jang laloe ada koerang teratoer, maka dengan soerat ini saja bertanja kehadapan Padoeka Toean tentang oemat Islam di Tana Toradja jang hendak naik Hadji tahoen ini, jang berjumlah koerang lebih tiga poeloeh orang. Oentoek mendjaga agar djangan kedjadian hal jang tidak menjenangkan bagi mereka, maka saja mohon soepaja sebeloem mereka berangkat dari Tana Toradja, lebih daholoe mendapat keterangan dari pada Padoeka Toean apa mereka terseboet bisa berangkat semoea atau tidak sebab sebagaimana jang kedjadian pada tahoen laloe di lain2 tempat, kebanjakan orang jang sudah mendjoal harta bendanja oentoek keperloean hadji, dan djoega telah mengeloearkan sebahagian ongkosnja ke Makassar akan tetapi sesampai di Makassar tidak djadi djoega pergi. Djadi harta habis didjoeal, maksoed tidak kesampaian, dan poelang kenegeri dengan doeka tjita." (ANRI Sulsel 1995 [Arsip Tana Toraja, No. Reg. 1416 dan 1420]:200)

Hal serupa terjadi di Onderafdeling Soppeng. Disebutkan 22 orang dari berbagai wanua yakni Wanua Pattodjo, Lalabata, Marioriwawo, Tjitta, Liliriadja, Lilirilau, dan Wanua Marioriawa gagal menunaikan ibadah haji padahal sebelumnya mereka telah menjual berbagai harta benda. Tercatat di Wanua Pattodjo, seorang yang bernama Abd. Gani teridentifikasi telah menjual harta bendanya berupa mesin jahit seharga $f 1.000$ (Rp300), sepeda seharga $f 450$ (Rp135), tanah kering seharga 300 (Rp90), sawah gadai seharga $f 300$ (Rp90). Sehingga total dari penjualan dan penggadaian 
tersebut sebanyak $f 2.050$ (Rp615 atau setara dengan 307 gram emas), nilai yang telah melebihi ongkos haji pada tahun 1949 (Faturrahman 2019:38).

Selain Wanua Pattodjo, hal yang sama ditemukan di Wanua Marioriwawo, tercatat sebanyak delapan orang menjual 11 ekor sapi seharga $f 2.800(\mathrm{Rp} 840), 1$ gilingan jagung seharga $f 500$ (Rp150), 2 palla kaju (pagar kayu) dengan masingmasing senilai $f 2.391$ (Rp717) dan $f 1.600$ (Rp480), serta 4 ekor sapi seharga $f 600$ (Rp180). Bahkan mereka menjual aset yang berada di luar wilayah Soppeng, yakni buah kelapa (kopra) di wilayah Toli-Toli Sulawesi Utara dengan nilai $f 2.500(\mathrm{Rp} 750)$. Selain penjualan barang, mereka menggadaikan sawah dengan nilai $f 1.000$ (Rp300) dan satu petak sawah senilai f250 (Rp75). Jadi total harta yang berhasil mereka kumpulkan sebanyak f11.641 (Rp3.492 atau 1.746 gram emas) (Faturrahman 2019:39).
Oleh karena itu, tidak mengherankan, pengorbanan yang besar itu membuat masyarakat Sulawesi Selatan pada masa awal kemerdekaan begitu menghargai seorang yang telah bergelar haji. Mereka dipadankan dengan golongan to sugi' (orang kaya) dan arung/karaeng (bangsawan) (Mattulada 2015).

Selain itu, seorang yang telah menjalani ibadah haji dipandang mencapai tingkat spritual yang lebih baik daripada masyarakat biasa. Ada prestise melekat pada pribadi yang telah melaksanakan ibadah haji.

Beberapa jemaah haji berasal dari golongan bangsawan juga ada yang ditunjuk negara sebagai pegawai dan delegasi haji. Di antara mereka, ada Andi Baso Datu Tanete dari Barru, Andi Mappa Datu Pattodjo dari Soppeng, Arung Soppeng Riadja, Andi Pabisieang Maradia dari Balanipa Mandar, dan Larigau Karaeng Galesong dari Makassar (Anonim 1953:623).

\begin{tabular}{|c|c|c|c|}
\hline $\begin{array}{l}\text { Dalam } \\
\text { tahun }\end{array}$ & Nama Delegasi & Nama Pegawai Negeri & Tempat Asal \\
\hline \multirow[t]{9}{*}{1947} & \multirow{9}{*}{$\begin{array}{l}\text { 1. H.A.S. Bachmid } \\
\text { 2. H.Darwis Zakariah } \\
\text { 3. H.A.Rachman Dg. Sitadja } \\
\text { 4. H.M. Busthami } \\
\text { 5. H.Baso Dg. Malewa } \\
\text { 6. H.Pontoh }\end{array}$} & 1. Andi Baso Datu Tanete & Barru \\
\hline & & 2. Andi Mappa Datu Pattodjo & Soppeng \\
\hline & & $\begin{array}{l}\text { 3. Andi Mangkona Arung } \\
\text { Matoa Wajo }\end{array}$ & Wajo \\
\hline & & $\begin{array}{l}\text { 4. Andi Makkulau } \\
\text { Tjakkuridia }\end{array}$ & Wajo \\
\hline & & $\begin{array}{l}\text { 5. Andi Baso Maradia } \\
\text { Balanipa }\end{array}$ & Mandar \\
\hline & & $\begin{array}{l}\text { 6. Andi Tjalo Sulawattang } \\
\text { Pinrang }\end{array}$ & Pinrang \\
\hline & & $\begin{array}{l}\text { 7. Dachlan Arung Soppeng } \\
\text { Riaja }\end{array}$ & Soppeng Riaja \\
\hline & & 8. Iskandar Arung Bodjo & Palopo \\
\hline & & 9. Iskandar Karaeng Marang & Makassar \\
\hline
\end{tabular}




\begin{tabular}{|c|c|c|c|}
\hline $\begin{array}{l}\text { Dalam } \\
\text { tahun }\end{array}$ & Nama Delegasi & Nama Pegawai Negeri & Tempat Asal \\
\hline & & 10. Karaeng Nasara & Sungguminasa \\
\hline & & 11. Karaeng Buah ri Takalar & Takalar \\
\hline & & 12. M. Dg. Manrapi & $\begin{array}{l}\text { Sulawesi Selatan, } \\
\text { (meninggal di } \\
\text { Makkah) }\end{array}$ \\
\hline & & $\begin{array}{l}\text { 13. Pananrang Sulawattang } \\
\text { Watampone }\end{array}$ & Bone \\
\hline \multirow[t]{13}{*}{1948} & \multirow{13}{*}{$\begin{array}{l}\text { 1. H. Husain Thaha } \\
\text { 2. H. Andi Patopoi } \\
\text { 3. H. Tom Olli } \\
\text { 4. A.S. Ali } \\
\text { 5. Srp. Aisjah } \\
\text { (perempuan) } \\
\text { 6. Srp. Nur } \\
\text { (perempuan) } \\
\text { 7. Srp. Intang } \\
\text { (perempuan) }\end{array}$} & 1. Andi Walino Arung Wage & Sengkang \\
\hline & & $\begin{array}{l}\text { 2. Andi Singke' Arung } \\
\text { Udjung }\end{array}$ & Soppeng \\
\hline & & 3. Mappa Arung Bulo Barat & Balanipa \\
\hline & & 4. Andi Pabiseang Maradia & Mandar, Balanipa \\
\hline & & $\begin{array}{l}\text { 5. Mattuladang Maradia } \\
\text { Tinambung }\end{array}$ & Mandar \\
\hline & & $\begin{array}{l}\text { 6. B. Dg. Matasa Karaeng } \\
\text { Kadjang }\end{array}$ & Bulukumba \\
\hline & & $\begin{array}{l}\text { 7. H. Ma'mun Qadhi } \\
\text { Mamudju }\end{array}$ & Mandar \\
\hline & & $\begin{array}{l}\text { 8. H. Zainuddin Jaksa Pare- } \\
\text { Pare }\end{array}$ & Pare-Pare \\
\hline & & 9. A. Karim Qadhi Majene & Mandar \\
\hline & & $\begin{array}{l}\text { 10. H. Abdurrahim Qadhi } \\
\text { Maros }\end{array}$ & Maros \\
\hline & & $\begin{array}{l}\text { 11. Larigau Karaeng } \\
\text { Galesong }\end{array}$ & Galesong \\
\hline & & $\begin{array}{l}\text { 12. Djaluddin Ammana Inda } \\
\text { Maradia }\end{array}$ & Mandar \\
\hline & & 13. Muddin Dg. Laba & Gowa \\
\hline 1949 & ---------------------------- & Tidak ada delegasi & $\begin{array}{l}\text { Hanya ada kepala } \\
\text { rombongan }\end{array}$ \\
\hline \multirow[t]{2}{*}{1950} & \multirow{2}{*}{$\begin{array}{l}\text { 1. H.A. Sewang Dg. } \\
\text { Muntu } \\
\text { 2. H.M.D. Dg. Tali }\end{array}$} & 1. Tumairilalang Lolo Gowa & Gowa \\
\hline & & $\begin{array}{l}\text { 2. Karto Prawira Mantri } \\
\text { Irigasi Bone }\end{array}$ & Bone \\
\hline
\end{tabular}

Tabel 1. Daftar nama delegasi dan pegawai yang ditunjuk negara pada rombongan ibadah haji tahun 1947-1950. Sumber: Anonim 1953:623.

Kehadiran para pegawai haji, selain itu terdapat indikasi bahwa pemerintah dalam rombongan ibadah keikutsertaan para pegawai pemerintah haji ini memberikan pesan bahwa ini sebagai dukungan moral yang negara hadir dalam pelaksanaan ibadah ditujukan para diplomat Indonesia 
meraih simpati dunia Islam dengan memanfaatkan momentum ibadah haji. Selain itu, hal ini juga dimanfaatkan untuk membina hubungan antara Saudi Arabia dengan Indonesia. Salah seorang delegasi haji Sulawesi Selatan H. A.S. Bachmid sepulang dari ibadah haji menyerahkan pedang emas tanda mata dari Raja Ibn Sa'ud kepada presiden NIT (Anonim 1948).

Sekadar catatan, kurun 1946-1950 adalah masa-masa genting bagi Indonesia dalam perjuangan mempertahankan kemerdekaan. Salah satu saluran yang digunakan adalah jalur diplomasi. Tercatat pada akhir 1948 utusan organisasi Missi Hadji Republik Indonesia diterbangkan ke Makkah, dipimpin oleh K.R.H. Mohd. Adnan dan beranggotakan H. Ismail Banda, Moh. Saleh Su'aidy, dan H. Sjamsir St. R. Ameh. Missi Hadji tersebut bertujuan mengibarkan bendera merah putih di Arafah. Setahun berikutnya pada 1949 menjelang berlangsungnya Konferensi Meja Bundar, pemerintah Republik Indonesia mengirimkan Missi Hadji Kedua dipimpin oleh Syech $\mathrm{H}$. Abdulhamid, S.R. H. Ameh Sjamsir, Mohammed Noer El Ibrahimy, Abdulkahar Muzakkir, Ali Hasjmy, dan Syeh Awab Sjahbal. Tujuan Missi Hadji kedua tersebut ialah berjumpa dengan para pemimpin dunia Islam, menjelaskan kepada mereka mengenai mata rantai dan tahap-tahap perjuangan Republik Indonesia, dan mengeratkan hubungan Indonesia dengan negara dan bangsa Islam serta bangsa Arab di Timur Tengah (Chambert-Loir 2013:737-738).
Vol. 4, No. 2, Juni 2021, hlm. 179-198

\section{Kopra dan Beras: Pendorong} Masyarakat Sulawesi Selatan dalam Menunaikan Ibadah Haji (1946-1950)

Pembeda motivasi berhaji pada masa sekarang dan masa lalu adalah fungsi penyematan gelar. Jika di masa sekarang gelar haji adalah perihal administrasi pencatatan sipil dan bukti mereka telah berhaji, maka di masa kolonial penyematan gelar haji diberikan untuk pengawasan pemerintah kolonial. Pengawasan ini dilakukan karena kekhawatiran masyarakat yang baru pulang dari haji menyebarkan paham Pan-Arab yang sangat kental dengan pemahaman nasionalisme yang berkelindan dengan semangat anti kolonialisme (Wibowo 2016).

Sebagaimana yang telah diuraikan sebelumnya, kuota haji untuk NIT berkisar pada angka 1.400-1.800 jiwa di mana $85 \%$ kuota tersebut diperuntukkan bagi Sulawesi Selatan. Hal tersebut berdasar pada catatan yang termaktub dalam Arsip Pemda Tana Toraja No. Register 1416. Pada 1947 sebanyak 1.482 jiwa masyarakat Sulawesi Selatan menunaikan ibadah haji (buku Republik Indonesia: Propinsi Sulawesi terbitan Kementerian Penerangan Republik Indonesia menyebutkan 1.491 jiwa).

Lalu, sebanyak 1.794 jiwa pada 1948 kuota jemaah haji untuk NIT di mana 1.664 jiwa di antaranya adalah jemaah haji dari Sulawesi Selatan (Anonim 1953). Sumber lain dalam arsip Pemda Toraja No. Register 1416 menyebutkan sebanyak 1.617 jiwa masyarakat pada masa tersebut menunaikan ibadah haji. Di tahun selanjutnya, terjadi penurunan jemaah 
haji yakni 925 jiwa (ANRI Sulsel 1995 [Arsip Tana Toraja, No. Reg. 1416:200).

Tren penurunan jumlah jemaah haji kembali terjadi di 1950 , tercatat sebanyak 811 jiwa (Anonim 1953). Penurunan angka pada 1949 dan 1950 dapat dikaitkan dengan permasalahan kuota yang dibatasi, sedangkan penurunan jumlah jemaah haji pada 1950 dikarenakan pecahnya peristiwa Andi Aziz yang menyebabkan terjadinya gangguan keamanan di Kota Makassar (Najamuddin 2000). Akan tetapi niat masyarakat Sulawesi Selatan untuk berhaji terbilang tinggi. Hal ini dapat dibuktikan dengan ditolaknya permohonan 12.000 calon jemaah haji pada 1949 karena keterbatasan kuota.

\begin{tabular}{|c|c|c|c|c|c|c|}
\hline \multirow[t]{2}{*}{ No } & \multirow{2}{*}{\multicolumn{2}{|c|}{ Afdeling }} & \multicolumn{4}{|c|}{ Tahun } \\
\hline & & & 1947 & 1948 & 1949 & 1950 \\
\hline 1 & \multicolumn{2}{|c|}{ Gementee Makassar } & 246 & 181 & 99 & 96 \\
\hline \multirow[t]{7}{*}{2} & \multirow[t]{7}{*}{ Makassar } & Gowa & 27 & 17 & 21 & 21 \\
\hline & & Maros & 80 & 100 & 39 & 50 \\
\hline & & Pangkajene & 81 & 50 & 62 & 80 \\
\hline & & Takalar & 7 & 6 & 15 & 10 \\
\hline & & Jeneponto & 39 & 30 & 18 & 15 \\
\hline & & Pulau-Pulau Makassar & - & - & - & $40 *$ \\
\hline & & Jumlah & 480 & 384 & 254 & 312 \\
\hline \multirow[t]{4}{*}{3} & \multirow[t]{4}{*}{ Bone } & Bone & 146 & 240 & 79 & 56 \\
\hline & & Soppeng & 76 & 111 & 48 & 34 \\
\hline & & Wajo & 187 & 258 & 132 & 93 \\
\hline & & Jumlah & 409 & 609 & 259 & 183 \\
\hline \multirow[t]{5}{*}{4} & \multirow[t]{5}{*}{ Bonthain } & Bonthain & 12 & 18 & 12 & 7 \\
\hline & & Bulukumba & 54 & 20 & 31 & 20 \\
\hline & & Sinjai & 26 & 13 & 5 & 10 \\
\hline & & Selayar & 9 & 5 & 17 & 5 \\
\hline & & Jumlah & 101 & 56 & 65 & 42 \\
\hline \multirow[t]{6}{*}{5} & \multirow[t]{6}{*}{ Pare-pare } & Sidenreng - Rappang & 221 & 192 & \multirow{3}{*}{177} & \multirow{3}{*}{136} \\
\hline & & Pinrang & 49 & 45 & & \\
\hline & & Pare-Pare & 88 & 119 & & \\
\hline & & Masenrenpulu & 7 & 8 & 7 & $5^{*}$ \\
\hline & & Barru & 42 & 47 & 21 & 17 \\
\hline & & Jumlah & 407 & 364 & 205 & 158 \\
\hline \multirow[t]{5}{*}{6} & \multirow[t]{5}{*}{ Mandar } & Majene & 40 & 100 & 54 & 43 \\
\hline & & Polewali & 41 & 74 & 60 & 49 \\
\hline & & Mamasa & - & - & 3 & 2 \\
\hline & & Mamuju & - & 14 & 11 & $7 *$ \\
\hline & & Jumlah & 81 & 188 & 128 & 101 \\
\hline \multirow[t]{5}{*}{7} & \multirow[t]{5}{*}{ Luwu } & Palopo & 4 & 16 & 4 & $4 *$ \\
\hline & & Masamba & - & - & 4 & $4 *$ \\
\hline & & Malili & - & - & 3 & $3 *$ \\
\hline & & Makale & - & - & 3 & 3 \\
\hline & & Jumlah & 4 & 16 & 14 & 14 \\
\hline
\end{tabular}

Tabel 2. Jumlah jemaah haji dari Sulawesi Selatan pada tahun 1947-1950. Sumber: Diolah dari Anonim 1953:615-620; ANRI Sulsel 1995 (Arsip Tana Toraja, No. Reg. 1420):200.

* Catatan : Angka yang tertera berdasar pada Arsip Pemda Toraja Nomor Register 1416 Surat Kawat tertanggal 5 Juni 1950.

DOI: $10.33652 /$ handep.v4i2.136 
Jika dianalisis dengan saksama dari tabel 2 tersebut di atas, akan didapati satu pertanyaan. Dari manakah mereka mendapatkan uang untuk mengongkosi ibadah hajinya? Sebenarnya ada satu benang merah antara jumlah masyarakat yang menunaikan ibadah haji dengan peningkatan ekonomi di Sulawesi Selatan. Ada dua komoditas utama yang menggerakkan roda perekonomian masyarakat Sulawesi Selatan dan Pemerintahan NIT di masa tersebut, yakni kopra (Asba 2007) dan beras (Akbar 2019).

Salah satu komoditas andalan daerah Sulawesi Selatan (selain kopra) dalam menopang laju pertumbuhan ekonomi adalah beras. Sejak lama (sekurang-kurangnya di abad ke-16) daerah ini dikenal sebagai sentra penghasil beras. Pires dalam catatannya menyebutkan bahwa beras telah menjadi komoditas dagang bagi masyarakat Sulawesi Selatan. Lebih lanjut ia mengemukakan bahwa masyarakat yang mendiami Sulawesi Selatan sejak dahulu dikenal sebagai pedagang dan pelaut ulung. Oleh karena itu, hubungan antara pelayaran dan perdagangan di kawasan tersebut tidak dapat dipisahkan (Pires 2014).

Setidaknya, di akhir 1949, terdapat dua belas negara yang menjadi tujuan ekspor kopra Sulawesi Selatan dengan total ekspor sebesar 168,148 metrik ton. Laporan keuangan NIT menunjukkan adanya pertumbuhan ekonomi yang pesat. Setidaknya dapat dilihat dari indikator harga kopra yang merangkak naik. Sebelum perang harga kopra berkisar antara $f 3.40$ per 100 kilogram pada 1940 , naik menjadi $f 42$ per 100 kilogram (Asba 2007:206-208). Wilayah penghasil kopra paling termasyur di Sulawesi Selatan adalah Afdeling Mandar.

Secara umum, laporan keuangan NIT menunjukkan bahwa perekonomian di negeri ini melaju pesat, kemajuan tersebut terkait meningkatnya ekspor kopra di Indonesia Timur. Pejabat daerah juga dilibatkan oleh pemerintah untuk mengawasi gudanggudang kopra agar para pedagang perantara dapat memanfaatkannya dengan baik (Sakka 2003:243-248). Hal tersebut dapat dilihat dari aktivitas Coprafonds di tiap-tiap pelabuhan di wilayah NIT.

\begin{tabular}{|c|c|c|c|c|c|}
\hline Tahun & $\begin{array}{c}\text { Indonesia } \\
\text { Timur }\end{array}$ & Makassar & $\begin{array}{c}\text { Manado dan } \\
\text { Gorotalo }\end{array}$ & $\begin{array}{c}\text { Dongala dan } \\
\text { Toli-Toli }\end{array}$ & $\begin{array}{c}\text { Bali, Lombok, } \\
\text { dan Maluku }\end{array}$ \\
\hline 1947 & 172,65 & 90,36 & 61,79 & 20,05 & - \\
\hline 1949 & 338,52 & 115,07 & 112,73 & 36,68 & 62,29 \\
\hline
\end{tabular}

Tabel 3. Pengiriman beras dalam lingkup NIT Tahun 1949. Sumber: Akbar 2019 dan diolah dari Economische Berichten Oost Indonesie, edisi 1-15 Januari; 15-31 Januari; 1-15 Februari; 15-28 Februari; 1-15 Maret; 16-31 Maret; 1-15 April; 1-15 Mei; 16-31 Mei; dan 1-15 Juni 1949.

Sebagaimana yang telah disebutkan, komoditas beras juga turut andil dalam memajukan perekonomian masyarakat Sulawesi Selatan. Pada 1949 dari periode Januari hingga Juni tercatat
7.485,40 ton beras diekspor dari Pelabuhan Makassar ke berbagai wilayah di Indonesia termasuk Papua New Guinea. 


\begin{tabular}{|c|c|c|c|}
\hline Bulan & $\begin{array}{c}\text { Periode } \\
\text { Pengiriman } \\
\end{array}$ & $\begin{array}{c}\text { Banyaknya } \\
\text { Pengiriman (ton) }\end{array}$ & Tujuan Pengiriman \\
\hline \multirow{3}{*}{ Januari } & 1-15 Januari & 998 & $\begin{array}{l}\text { Maluku, Sunda Kecil, Lombok Tengah, Lombok } \\
\text { Selatan, dan Lombok Tenggara, dan NIT }\end{array}$ \\
\hline & 1-15 Januari & 156 & Nieuw Guinea \\
\hline & 15-31 Januari & 2000 & Sunda Kecil, Sumba, Flores, dan Timor \\
\hline \multirow{3}{*}{ Februari } & 1-15 Februari & 400 & NIT termasuk Sunda Kecil \\
\hline & 1-15 Februari & 60 & Pulau Irian \\
\hline & 15-28 Februari & 400 & Dalam lingkup NIT \\
\hline \multirow[b]{2}{*}{ Maret } & 1-15 Maret & 601 & Dalam lingkup NIT dan Sunda Kecil \\
\hline & 16-31 Maret & 850 & $\begin{array}{c}\text { Beberapa lokasi di NIT dan Sunda Kecil } \\
\text { termasuk Kupang Selatan, Lombok Barat } \\
\text { Daya,dan Lombok Tenggara }\end{array}$ \\
\hline \multirow{2}{*}{ April } & 1-15 April & 928 & Beberapa lokasi di NIT \\
\hline & 1-15 April & 132 & Pulau Irian \\
\hline \multirow{4}{*}{ Mei } & 1-15 Mei & 40 & Waingpau, Sunda Kecil \\
\hline & $1-15 \mathrm{Mei}$ & 274,50 & Beberapa lokasi di NIT \\
\hline & 16-31 Mei & 186,90 & Beberapa lokasi di NIT \\
\hline & 16-31 Mei & 132 & Pulau Irian \\
\hline \multirow{2}{*}{ Juni } & 1-15 Juni & 168 & Beberapa lokasi di NIT \\
\hline & 1-15 Juni & 159 & Pulau Irian \\
\hline Total & Januari - Juni & $7.485,40$ & NIT dan Nieuw Guinea \\
\hline
\end{tabular}

Tabel 3. Pengiriman beras dalam Lingkup NIT Tahun 1949. Sumber: Akbar 2019 dan diolah dari Economische Berichten Oost Indonesie, edisi 1-15 Januari; 15-31 Januari; 1-15 Februari; 15-28

Februari; 1-15 Maret; 16-31 Maret; 1-15 April; 1-15 Mei; 16-31 Mei; dan 1-15 Juni 1949.

Sejak 1900 hingga 1930 harga beras dilaporkan naik sangat tinggi, dan 1930-1940 terjadi penurunan harga beras sampai Perang Dunia II berakhir, laporan tentang harga beras hanya sebatas daerah Jawa saja (Linblad et al. 2000:333-369). Namun laporan-laporan tentang perekonomian dan beras di luar Jawa mulai nampak pada paruh awal hingga pertengahan abad ke-20 (Creutzberg 1987:113-123).

Secara umum, konsumsi beras di Indonesia sejak 1948-1950 secara berturut-turut 80,83 , dan 82 kilogram. Adapun konsumsi beras di daerah di luar Jawa dan Madura yakni 100 kilogram perkapita dalam setahun (BULOG 1970:5). Adapun harga beras rata-rata di Indonesia pada 1948 ialah Rp0.985 (98,50 sen), pada 1949 ialah Rp1.13, dan pada 1950 ialah Rp1.08 untuk tiap-tiap satu kilogramnya (BULOG 1970)

Untuk Sulawesi Selatan, pada 1948 harga beras rata-ratanya ialah 25 sen per liternya. Harga tersebut merupakan harga yang paling murah, sedangkan harga yang paling mahal ialah 70 sen. Harga beras termurah didapatkan di Wattampone, Onderafdeling Bone. Sedangkan harga beras termahal didapatkan di Majene, Afdeling Mandar. Perbedaan harga tersebut dipandang wajar mengingat Onderafdeling Bone merupakan daerah penghasil beras sedangkan Afdeling Mandar lebih dikenal sebagai daerah penghasil kopra.

Secara makro, kegiatan ekspor dua komoditas tersebut tentunya memengaruhi perekonomian Sulawesi Selatan, hal tersebut berdampak pada 
Handep Jurnal Sejarah dan Budaya Vol. 4, No. 2, Juni 2021, hlm. 179-198

peningkatan kesejahteraan masyarakat Sulawesi Selatan, baik di daerah penghasil beras maupun di daerah penghasil kopra. Salah satu indikator dari pernyataan ini adalah adanya benang merah antara banyaknya jumlah jemaah haji dari wilayah penghasil beras dan kopra. Dapat disebutkan afdeling penghasil beras, seperti Bone, Pare-Pare, dan Makassar memiliki jumlah jemaah haji sebanyak 4.029 jiwa pada 1947-1950. (Anonim 1953:615-620). Adapun jumlah jemaah haji di wilayah penghasil kopra Afdeling Mandar ditambah wilayah Onderafdeling Selayar adalah sebanyak 534 jiwa pada 1947-1950 (ANRI Sulsel 1995 [Arsip Tana Toraja, No. Reg. 1416]:200).

Dari ulasan fakta sejarah di atas, dapat ditarik simpulan bahwa faktor pendorong banyaknya masyarakat Sulawesi Selatan menunaikan ibadah haji adalah berkembangnya perekonomian di daerah tersebut yang ditunjang melalui kegiatan perdagangan beras dan kopra. Jika ditelisik lebih mendalam, wilayah penghasil beras lebih banyak menyumbang jemaah haji daripada wilayah penghasil kopra.

Hal ini dapat dianggap wajar karena produk pertanian atau komoditas beras menyentuh pada setiap aspek dan lini kehidupan masyarakat. Beras hadir pada tataran masyarakat kelas bawah hingga kelas atas.

Pernyataan ini sesungguhnya dapat didukung oleh fakta korespondensi pemerintah fakta. Pada 27 Juni 1949, pihak E. Haug, kontrolir yang diperbantukan Keresidenan Sulawesi Selatan, menyurat ke berbagai afdeling untuk meminta keterangan mengenai masyarakat Sulawesi Selatan yang tidak berangkat haji dikarenakan kuota yang terbatas. Dalam surat itu disebutkan tentang fenomena masyarakat yang harus menjual segala harta bendanya, termasuk sumber penghidupan utamanya yakni sawah. Penjualan harta untuk menutupi ongkos haji tersebut termuat dalam nukilan surat yang dikirim oleh E. Haugkepada para bestuur (pegawai) di Palopo, Makale, Masamba, dan Malili yang bunyinya berikut.

Termuat dalam verslag dari salah satu dari Kepala Afdeling, bahwa ada banjak orang jang tidak mendapat tempat untuk perdjalanan naik Hadji jang akan datang, terlebih dahulu sudah didjadikan wang dengan harta2nja (sawah2, kebun2, rumah2 dsb.) untuk dipergunakan menutup ongkos2 jang bersangkutan dengan perdjalanan naik Hadji tersebut. Diminta pada P. Tuan dengan sangat, apabila hal ini terdjadi djuga dalam Afdeling P.Tuan setjara besar2an, dichabarkan nanti kemari pada kami. (ANRI Sulsel 1995 [Arsip Tana Toraja, No. Reg. 1416]:200)

Menyitir dari pernyataan sebelumnya, banyaknya masyarakat yang menunaikan ibadah haji membuktikan bahwa terjadi peningkatan perekonomian masyarakat Sulawesi Selatan pada periode 1946-1950. Hal ini dikarenakan dampak positif dari perdagangan beras dan kopra yang dilakukan oleh masyarakatnya. 


\section{SIMPULAN}

Pada awalnya, kisaran abad ke-15 hingga abad ke-18, penduduk di Nusantara yang melaksanakan ibadah haji merupakan para pedagang, utusan sultan, serta musafir penuntut ilmu. Pada perkembangan selanjutnya, masyarakat dari kalangan biasa mulai turut dalam perjalanan ibadah haji dengan menumpang kapal yang berlayar menuju Tanah Hejaz. Ketika memasuki abad ke-20, terutama masa awal kemerdekaan, animo masyarakat menunaikan ibadah haji terbilang tinggi walaupun negara berada dalam suasana perang untuk mempertahankan kemerdekaan.

Salah satu daerah di Indonesia yang memiliki animo tinggi dalam menunaikan ibadah haji pada periode 19461950 adalah Sulawesi Selatan. Hal ini dapat dibuktikan dengan banyaknya permohonan calon jemaah haji berjumlah lebih kurang 12.000, walaupun pada kenyataannya hanya kisaran 1.000-2.000 calon jemaah haji yang mendapatkan kesempatan berhaji.

Ada beberapa faktor mengapa hanya sedikit yang mampu menunaikan ibadah haji di masa tersebut yakni, keterbatasan kuota dan mahalnya biaya berhaji. Untuk memenuhi biaya haji tersebut, para calon jemaah haji rela menjual sebagian harta bendanya serta melakukan usaha perdagangan terutama komoditas beras dan kopa.

Komoditas beras dan kopra turut mendukung masyarakat Sulawesi Selatan untuk berhaji terutama pada masa NIT (1946-1950). Mereka yang menunaikan ibadah haji pada masa tersebut diduga kuat berprofesi sebagai petani kopra dan pedagang beras (seorang yang bekerja sebagai petani). Hal itu inheren dengan banyaknya jemaah haji yang berasal dari wilayah penghasil beras dan kopra.

Dari hasil perdagangan beras dan kopra serta menjual berbagai harta benda dijadikan suatu modal dalam memberangkatkan seseorang berhaji di kurun tahun tersebut. Perilaku tersebut terkait dengan predikat haji sebagai prestise dalam status sosial. Bagi masyarakat Sulawesi Selatan, orang yang telah bergelar haji diberikan penghormatan sosial selayaknya penghormatan kepada kaum bangsawan.

\section{DAFTAR SUMBER}

Adhan, Syamsurijal, Musafir Pababari, Muhammad Ramli, dan Wahyuddin Halim. 2020. "Aji Ugi: Pergumulan Islam dengan Tradisi Lokal dan Gaya Hidup di Masyarakat Bugis." Al Qalam 26(1):19-38.

Ahmad M. Sewang. 2005. Islamisasi Kerajaan Gowa (Abad XVISampai Abad XVII). Jakarta: Yayasan Obor Indonesia.

Akbar, Adil. 2016. "Perdagangan Beras di Sulawesi Selatan 19471956." Skripsi, Universitas Negeri Makassar, Makassar. . 2019. "Jaringan Pelayaran

dan Perdagangan Beras di Sulawesi Selatan pada Tahun 19461950." Tesis, Universitas Negeri Makassar, Makassar.

Anonim. 1948. Djema'ah Hadji Tahoen Hidjrah 1367 dari "Negara 
Indonesia Serikat." Djakarta:

Djawatan Penerangan Pemerintah. . 1949. "Economische Berichten Oost Indonesie-Warta Berita Ekonomi Indonesia Timur." Januari-Juni. . 1953. Republik Indonesia: Propinsi Sulawesi. Makassar: Kementerian Penerangan.

ANRI-SULSEL. 1995. Inventaris Arsip Tana Toraja 1901-1959. Nomor Register 1416, 1417, 1420.

Asba, Abdul Rasyid. 2007. Kopra Makassar: Perebutan Pusat dan Daerah: Kajian Sejarah Ekonomi Politik Regional di Indonesia. Jakarta: Yayasan Obor Indonesia.

Azyumardi, Azra. 2004. Jaringan Ulama Timur Tengah dan Kepulauan Nusantara Abad XVII Dan XVIII. Bandung: Mizan.

BULOG. 1970. Seperempat Abad Bergulat dengan Butir-Butir Beras. Jakarta: Badan Urusan Logistik.

Chambert-Loir, H. 2013. Naik Haji di Masa Silam: Kisah-Kisah Orang Indonesia Naik Haji, 1482-1964, Cetakan Pertama. Ed, Naskah dan Dokumen Nusantara. Jakarta: KPG (Kepustakaan Populer Gramedia) bekerja sama dengan École française d'Extrême-Orient (EFEO), Forum Jakarta-Paris, Perpustakaan Nasional, Republik Indonesia.

Creutzberg, Pieter \&. J. T. van Laanen. 1987. Sejarah Statistik Ekonomi
Indonesia. Jakarta: Yayasan Obor Indonesia.

Faturrahman, Ahmad. 2019. "Berhaji pada Masa Kolonial Selebes Selatan 1947-1950." Skripsi, Fakultas Adab dan Humaniora, Universitas Islam Negeri Alauddin, Makassar.

Limpo, S.Y., Culla, A.S., Tika, Z. 1995. Profil Sejarah, Budaya, dan Pariwisata Gowa. Sungguminasa: Pemerintah Daerah TK.II Gowa Kerjasama dengan Yayasan Eksponen 1966.

Madjid, M.S., Hamid, A. R. 2011. Pengantar Ilmu Sejarah. Yogyakarta: Penerbit Ombak.

Mattulada. 2015. Latoa: Antropologi Politik Orang Bugis. Yogyakarta: Penerbit Ombak.

Muhammadiyah, Hilmi. 2006. "Haji dan Reposisi Perempuan Bugis: Upaya Meningkatkan Status Sosial pada Masyarakat di Sulawesi Selatan." Tesis, Universitas Indonesia, Depok.

Najamuddin. 2000. "Sulawesi Selatan: Pergumulan Antara Negara Federal dan Negara Kesatuan 1946-1949." Tesis, Fakultas Ilmu Pengetahuan Budaya, Universitas Indonesia, Depok.

Noorduyn, J. 2018. Islamisasi Makassar. Yogyakarta: Penerbit Ombak.

Nur, Nahdia. 2003. "Produksi dan Pemasaran Beras di Sulawesi 
Selatan 1900-1943." Tesis, Fakultas Ilmu Budaya, Universitas Gadjah Mada, Yogyakarta.

Pires, Tome. 2014. Suma Oriental: Perjalanan dari Laut Merah ke Cina dan Buku Francisco Rodrigues. Yogyakarta: Penerbit Ombak.

Priyadi, S. 2015. Historiografi Indonesia. Yogyakarta: Penerbit Ombak.

Putuhena, M. S. 2007. Historiografi Haji Indonesia. Yogyakarta: LKiS.

Rahman, A. 2015. Filsafat Sejarah. Makassar: Rayhan Intermedia.

Rifal. 2013. "Haji dan Status Sosial di Kecamatan Kajuara Kabupaten Bone (2007-2011)." Skripsi, Universitas Negeri Makassar, Makassar.

Rohmatulloh, Dawam Multazamy. 2017. "Perjalanan Haji Indonesia Di Masa Kolonial." QALAMUNA: Jurnal Pendidikan, Sosial, dan Agama 9(02):115-27.

Sakka, Abdul Rasyid A. Ambo. 2003. "Ekspansi dan Kontraksi Ekspor Kopra Makassar 1883-1958." Disertasi, Universitas Indonesia, Depok.

Shariati, A. 2009. Haji. Bandung: Pustaka Bandung.

Sjamsuddin, Helius. 2007. Metodologi Sejarah. Yogyakarta: Penerbit Ombak.
Undang-Undang Republik Indonesia Nomor 19 Tahun 1946 tentang Pengeluaran Uang Republik Indonesia.

Vredenbregt, J. 1997. Ibadah Haji: Beberapa Ciri dan Fungsinya di Indonesia. Jakarta: INIS.

Wibowo, E. Y. 2016. "Pengaruh Haji Terhadap Politik Islam di Indonesia (Tahun 1900-1945)." Jurnal Bahasa, Peradaban dan Informasi Islam 16(1):34-52. 
